material under treatment and the solid fuel are kept apart, and the flame and hot gases from the burning fuel enter the furnace proper at one end and are deflected or beaten down on to the material on the hearth by the roof of the furnace. The earliest account of such a furnace was given by Theophilus the monk, who wrote in the eleventh century. It was used for making glass. Early in the sixteenth century reverberatory furnaces were used in Germany for melting bronze for guns, but Agricola in his " $\mathrm{De}$ re metallica" makes no mention of them. The earliest description in the English language of a reverberatory furnace was found in a work published in 1613 by John Rovenson, while the earliest drawing of any value of a coal-burning reverberatory furnace was given by the German metallurgist Schlüter in his "Gründlicher Unterricht von Huttenwerken" of 1738. During the seventeenth century the smelting of lead, copper and iron in reverberatory fumaces was attempted by various individuals at several places; the furnaces being generally without chimneys. An interesting point was when was it recognised that with a closed fireplace the air required for the combustion of the fuel could be drawn through by a chimney. The first record of the use of chimney draught is contained in Glauber's work of 1646 "Furni novi Philosophici", translated into English in 1651 .

\section{Petrie Portrait Fund}

The retirement of Sir Flinders Petrie from the Edwards professorship of Egyptology at University College, London, has seemed to many of his friends an appropriate occasion for an expression of appreciation of his lifelong services to archæology. It is thought that this might most appropriately take the form of his portrait, to be presented to the College with which he has so long been associated. An appeal for funds for this purpose has been issued over the names of Prof. J. H. Breasted, M. J. Capart, Dr. Howard Carter, Prof. F. Ll. Griffith, Sir George Hill, Sir Henry Lyons, Dr. Allan Mawer, Sir Robert Mond and Dr. Margaret Murray. In issuing the appeal, it is pointed out that it is now more than fifty years since Sir Flinders began work as an archæologist at Stonehenge, and soon afterwards carried out the first accurate survey of the Pyramids at Gizeh. Referring to his influence on archæological studies during his long career as an excavator, the committee states no more than the bare truth when it points to his insistence on accurate observation and recording, and the stress he has laid on the significance of smaller finds, equally with the larger, in an excavation, in developing knowledge of the social conditions of the past. The appeal also refers to his early recognition of the importance of correlation in studying the intercourse between the various peoples of the Near East from earliest times. Finally, in attributing to him in large measure the awakening of modern interest in archæology, mention is made of the great number of archæologists who have achieved distinction after receiving their training and inspiration from him as lecturer and excavator. Subscriptions towards the fund will be received by Sir Henry
Lyons, F.R.S., 3 York Terrace, Regent's Park, London, N.W.1.

\section{Infra-Red Photography as an Aid to Navigation}

THE United States liner Manhattan has recently been fitted with a special look-out camera intended for an investigation of fog penetration with infra-red sensitive materials. Mechanism for the automatic developing and fixing of the photographs is included in the body of the camera itself, and the photographic record may be viewed one minute after the exposure has been made. The weather conditions encountered by the Manhattan since the new apparatus was installed have not been suitable for experimental work, so no records obtained under service conditions are yet available. The problem of fog penetration is not at all simple, and it remains to be seen whether the degree of penetration actually obtained by this method will be really helpful to navigators.

\section{The Gases of the Atmosphere}

Is his presidential address before the Royal Meteorological Society at its annual general meeting on January 17, Prof. S. Chapman discussed "The Gases of the Atmosphere". The permanent gases of the atmosphere (mainly nitrogen and oxygen) are known, from direct measurements in the stratosphere, to be in constant proportions up to the greatest heights yet attained by Piccard and his successors in stratospheric flight. Other constituents vary in their concentration, because of processes tending to produce and destroy or transfer them in the atmosphere: among such constituents are water, ozone and the newly discovered positrons, which enter the atmosphere from outside as cosmic rays. Experiments were suggested to determine the rate of large. scale transfer of such gases by turbulence, using some easily detectable gas, artificially introduced, as an 'indicator'. Such experiments might also be made using ozone as the indicator, which would throw light on the distribution of ozone, as recently estimated by Dobson, Götz and Meetham. The possibility of removing the atmospheric ozone above certain ground areas was also considered. The absorption of solar radiation by oxygen and ozone was discussed in the light of new experimental data, and in relation to the composition and temperature of the upper atmosphere.

\section{London's Underground Railways}

BY the formation of the London Passenger Transport Board last year, the unification of the underground train, bus, trolley-bus and tram systems of London has been accomplished. The British Electrical and Allied Manufacturers Association (Beama) has recently published a well-illustrated book giving an account of the part played by British manufacturers' in providing machinery and equipment for this great transport service. The account given proves the sound administrative qualities of those who have made London's 'Underground' the foremost institution of its kind in the world. So far back as 1846 , the prospectus which led to the foundation of the 